\title{
How do clergy in the Afrikaans-speaking churches deal with sexuality and HIV prevention in young people? Is the message clear?
}

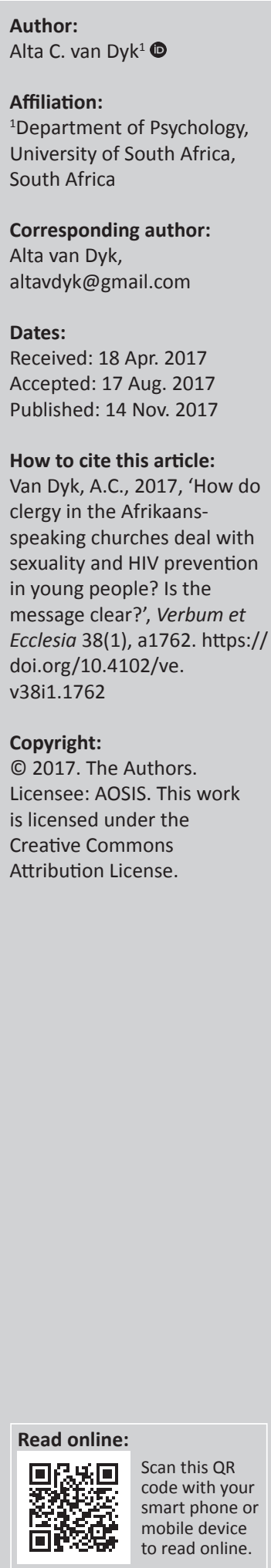

The purpose of this study was to investigate how clergy are dealing with HIV prevention and sexuality education of young people in their congregations. An electronic questionnaire was filled in by 142 clergy from white Afrikaans-speaking churches in the Reformed tradition. Results showed that 77\% clergy believed that unmarried young people in their congregations are sexually active. More than $85 \%$ clergy agreed that it is the task of the church to provide sexuality and HIV prevention education to young congregants. However, not many clergy (13\%) offered HIV prevention programmes for young people in their own congregations. The main HIV prevention message $85 \%$ of clergy were prepared to share with young congregants was 'abstinence only' or 'your body is the temple of God'. Only 15\% clergy (significantly more female clergy) were prepared to offer comprehensive sexuality education (abstinence PLUS) programmes. The HIV prevention message of the church should at least be in line with the lived experiences and reality of its youth in today's society. The church can no longer afford to alienate young people through moralism only. She needs an approach that satisfies both morality and reality.

Intradisciplinary and/or interdisciplinary implications: This article has implications for the fields of psychology, HIV and AIDS research and pastoral care. It challenges the way the church prepares young people to cope with HIV in a modern society and suggests change in terms of a greater participation in the sexuality education of young people.

The role of schools and religious and civic organisations is extremely important in the fight against HIV. We should empower our youth with education and life skills they need to prevent themselves from being infected with HIV, and that will help them to become compassionate, caring members of a society that will be struggling with the aftermath of AIDS for a long time to come. (Van Dyk, Tlou \& Van Dyk 2017:252)

\section{Introduction}

South Africa, like other countries in sub-Saharan Africa, has been hit very hard by the HIV epidemic, and especially young people between the ages of 15 and 24 are cause for great concern. What is not clear, however, is to what extent HIV is also a problem among white Afrikaansspeaking youth from faith communities. Is it a problem that is so small that it can be ignored by the church, or are the Afrikaans-speaking churches living in a fools' paradise by assuming that HIV is almost exclusively a problem in black communities or in non-faith communities?

In their latest survey on HIV prevalence, incidence and behaviour in South Africa, the Human Sciences Research Council (HSRC) reported an overall HIV prevalence of $7.1 \%$ among young people aged between 15 and 24 years, with an increase of $18.8 \%$ in the age group between 15 and 49 years old (Shisana et al. 2014:40-42). One-tenth (10.9\%) of young people who participated in the HSRC survey had sex before the age of 15 years, and $22.4 \%$ reported having multiple sex partners during the preceding year. Condom use was also very low, with $41.6 \%$ of young people saying that they did not use a condom the last time they had sex (Shisana et al. 2014:65-71).

Although the HSRC study sample ( $n=38$ 431) was representative of the population of South Africa in terms of sex, age and locality, the figures for white South Africans were unrepresentative because of a low response rate from this part of the population (Shisana et al. 2014:XXVIII). The fact that a very low HIV prevalence of only $0.3 \%$ was thus reported among white participants should therefore be approached with the necessary caution.

In their study on the 'spiritual wellbeing and lifestyle choices' among Afrikaans-speaking Grade 10 learners from five schools in the Limpopo Province of South Africa, Jacobs, Viljoen and Van der 
Walt (2012:93) found that $10.8 \%$ of the learners had experimented with sex before. Some of these learners already had their sexual debut at a much younger age while $6.7 \%$ of them have integrated sex as part of their lifestyle at this young age.

Although some controversy exists in scientific literature over the question if religious youth will be less inclined to have sex than non-religious youth (see for example Stephenson, Simon \& Finneran 2014; Yaw Amoateng \& Kalule-Sabiti 2013), some researchers found that many church-going youth in South Africa are sexually active and that there is no difference between the sexual activities of religious versus non-religious adolescents (Bornman 2013; Erasmus \& Le Roux 2008; Mash \& Mash 2013; Mash, Kareithi \& Mash 2006). One example is a study by the Anglican Church in Cape Town that showed that $30.5 \%$ of 1306 church-going youth between the ages of 12 and 19 years have had sex before, with only 35\% using condoms when they had sex for the first time (Mash et al. 2006:124-127). Promiscuity was also common in this group with $66 \%$ of sexually active church-going youth reporting that they had more than one sex partner.

To assume that white Afrikaans-speaking adolescents, and more specifically church-going youth, are safe, and that sexuality and HIV prevention education is not necessary among this sub-group, would therefore be irresponsible. This begs the question if it should be the task of the church to provide sexuality and HIV prevention education to adolescents in their congregation.

\section{Why the church should provide HIV prevention education}

The church in Africa has historically played an important role in formal education of a more general nature. During the past decades, the role of the church in providing formal education has, however, greatly diminished in South Africa. According to Jansen, Pretorius and Van Niekerk (2009) HIV has caused a new challenge to the church in contemporary Africa to provide formal sexuality and HIV prevention education:

... the role of the Christian church is becoming more important, and the increasing complexity of the problematic issues in Africa implies that the church will have to rethink its role in education. (p. 68)

Faith communities, religious leaders and the church are increasingly regarded as important partners in providing HIV-related health services to young people, including the prevention of HIV (Gold et al. 2010; Nweneka 2007; Mash \& Mash 2013:3; Mpofu et al. 2014:966). Some of the advantages of the church in HIV prevention work are its credibility in society, accessibility, extensive communication networks and infrastructure. There is a church in every community in the country, including the most remote and smallest of towns. It also has the infrastructure in terms of space and educational materials as well as the personnel, who may be willing to educate young people about sexuality and the prevention of
HIV and other sexually transmitted infections (STIs) (also see Jansen et al. 2009:77).

Studies showed that young people in Africa perceived faithbased organisations (FBOs), including the church, as more acceptable and trustworthy to offer HIV prevention messages than government or foreign organisations, mainly because the church is part of the local culture (Blevins 2016:3; Mash \& Mash 2013). The church is the one place in a community where young people may feel safe, where they come together to participate in various activities, where they could find support, counselling and moral guidance and where they get a feeling of belonging and meaningfulness (Eriksson et al. 2013:462). For example, religious leaders - especially youth leaders - were seen as 'the most trusted educators on sexuality' by young people in KwaZulu-Natal who participated in a study conducted by Eriksson et al. (2014:1666). On the other hand, Bornman (2013:4) found that although the church is the most popular place for young people to socialise (after sport gatherings), this is not necessarily a reflection of the true influence of the church on the sexual behaviour of young people.

These somewhat contradictory results may suggest that although adolescents may trust the church to provide them with sexual education they do not necessarily follow the advice of the church to remain sexually inactive until they get married. This conclusion suggests that the potential role of the church in preventing HIV infection may be more complex than assumed by many clergy.

\section{The dilemma of the church}

Blevins (2016:27) described religion as a double-edged sword when it comes to HIV. On the one hand the church and FBOs have excelled in providing care, treatment and support to people infected and affected by HIV, but when, on the other hand, it comes to HIV prevention, sexual and reproductive health services, the church often struggles, falters and fails (Denis 2009:66-81). Genuis (2010:185) attributed this discrepancy to the religion or moral versus science dichotomy. Church leaders and clergy may therefore find it difficult to combine medical and scientific guidelines (on HIV prevention) with the strict moralistic message of 'total abstinence until marriage' and 'absolute faithfulness thereafter'. The difficulty to deal with aspects of human sexuality, other than morals, is therefore a huge obstacle in ensuring the church's involvement in HIV prevention (Eriksson et al. 2014:1663). Rather than helping, the moralistic view of the church that sexual intercourse outside marriage is sinful is therefore an important barrier preventing churches from becoming involved in HIV prevention programmes for the youth.

Researchers, who work in the field of religion, youth and sexuality are in agreement that the main message of the church to young people on how to prevent HIV infection is generally a message of 'abstinence only' until marriage (Eriksson et al. 2013, 2014:1668; Francis 2009:6; 
Santelli et al. 2006:85). Various scholars found that although 'abstinence only' messages sometimes have the positive effect that young people may delay their sexual debut, these messages have no effect on the same young people's sexual behaviour once they start having sex. 'Abstinence only' messages did not prepare them to protect themselves from HIV and STIs once they were sexually active (Garner 2000:46). Apart from the church's silence on HIV prevention, her condemnation of premarital sex and condom use as sinful makes it very difficult for young church-going youth to protect themselves and their partners (Mash \& Mash 2013:4; Rostosky 2004:677; Zaleski \& Schiaffino 2000:226).

The message of 'abstinence only' is further in conflict with the lived experiences of many young South African churchgoers who find it extremely difficult to abstain from sex because of peer pressure, gender power relations, the influence of television and social media, the availability of drugs and alcohol, the tendency to marry at a more mature age and the perception that sex is always part of a relationship or that 'love equals sex' (Burchardt 2011:669; Eriksson et al. 2013:462). In their article on a social-constructionist narrative understanding of the Church's morality on sex, Müller and Pienaar (2003:138) also commented on the general shift in sexual morality that took place in South Africa since the 1980s where young people cohabit before marriage and do not accept that they are 'living in sin'.

A message of 'abstinence only' in a context where young people are already sexually active is therefore often deemed irrelevant and inappropriate and will make no difference to the behaviour of young people. Nweneka (2007:969) supported this view with his finding that only $19 \%$ of all the sexually experienced youth in his study practised abstinence. He further found that condom use in sexually active youth increased from $24 \%$ (of those who heard 'abstinence only' messages) to $43 \%$ once they were exposed to a combined message of 'preferred abstinence' plus condom use, if abstinence is not desirable. He concluded that a combination of different HIV prevention strategies would be more effective in empowering young people to be safe than preaching abstinence only.

Blevins (2016:37) made a valid point when he said that many children were saved and given a chance to a full, healthy and productive life through the availability of antiretroviral treatment to pregnant women and to children born with HIV. Should we now let them die as they grow from childhood to adolescence because of tension between comprehensive sexual health education and religious teachings about sexuality and sexual behaviours?

\section{Purpose of the study and research questions}

To get a fair indication of the sexual activity or inactivity of the white youth in Afrikaans-speaking churches (and thereby the potential problem of HIV within this group) and to assess the role the church can play in the prevention of HIV, a comprehensive survey among both the youth and the clergy of these churches would be necessary. The limited purpose of this study was to do a preliminary investigation on how clergy in the white Afrikaans-speaking churches in the Reformed tradition are dealing with sexuality and HIV prevention in young people in their congregations. The research questions were as follows:

- What are clergy's perceptions about the sexual behaviour of young people in their congregations?

- Do clergy think that it is the task of the church to provide sexuality education to young people in their congregations?

- What are clergy doing in their congregations to educate young people about HIV prevention?

- What is the main HIV prevention message that clergy are prepared to share with their young congregants?

\section{Research design}

An empirical survey was conducted among clergy in the white Afrikaans-speaking churches in the Reformed tradition to determine how they are dealing with HIV prevention in young people in their congregations. E-mails were sent to all clergy whose email addresses were available on the Internet and in church publications. The purpose of the research was explained to clergy and if they were willing to participate in the research, they received a link to a Web address where they could complete an electronic online questionnaire.

\section{Sample}

The sample consisted of clergy within the white Afrikaansspeaking churches in the Reformed tradition. It therefore included ministers in the 'Nederduits Gereformeerde' (NGK), 'Nederduitsch Hervormde' (Herv), 'Gereformeerde' (Geref) and 'Afrikaanse Protestantse' (APK) churches in South Africa, Namibia and Zimbabwe with available email addresses $(n=2543)$. The sample should be seen as a convenient sample (see Coolican 2004:42) because it excludes all clergy without email addresses. Although sampling attempted to avoid any bias in terms of gender, age and geographic location, it should be noted that the results will mostly reflect the views of older white Afrikaans-speaking men because of the nature of the population sampled. For historical reasons, clergy in the Afrikaans-speaking churches are mostly male and above 40 years old.

It was clearly stated that clergy were under no obligation to fill in the questionnaires. Because of the nature of the electronic survey, the anonymity of clergy as well as the names of their congregations was guaranteed because neither would be known to the researcher. Ethical clearance to conduct the research was obtained from the Department of Psychology and the College of Human Sciences at Unisa.

\section{Measuring instrument}

A structured electronic questionnaire developed in Google forms was used for the survey. Participants only had to click 
on the alternative of their choice. The questions were mainly in the format of ordinal four-point Likert scales ranging from 'strongly disagree' to 'strongly agree' with a few 'Yes or No' questions. Data from Google forms were directly exported error-free to IBM SPSS Statistics for data analysis.

Over and above demographic information (age, gender, highest theological qualification, church affiliation and city or rural congregation) each one of the research questions (see above) was addressed in the questionnaire (Do clergy think that young congregants are sexually active? Is it the task of the church to provide HIV prevention education? What are clergy doing in their congregations to prevent HIV? What is the main HIV prevention message to young congregants?).

\section{Techniques of data analysis}

Descriptive and inferential statistical analyses were performed by using the software programme IBM SPSS version 24. The four-point Likert scale items were coded to range from 1 (strongly disagree) to 4 (strongly agree). The results of the individual Likert items will be reported for (1) agree or strongly agree and (2) disagree or strongly disagree.

\section{Results}

\section{Demographic attributes of participants}

The questionnaire was completed by 142 participants, representing a return rate of $5.6 \%$. The mean age of the participants was 52.28 years $(\mathrm{SD}=11.46$; minimum age $=25$ and maximum age $=75$ ) with $81 \%$ being older than 40 years. Most of the participants were men (91.5\%) with only $8.5 \%$ women, which is a reflection of this male-dominant occupation. Most of the participants (69\%) had a Master's degree or higher. Most of the clergy was in the NGK Church (76.8\%), with $9.9 \%$ in the Herv Church, 9.2\% in the Geref Church and $4.2 \%$ in the APK Church. The congregations of the participants were mostly situated in cities or major towns $(65.5 \%)$ with $34.5 \%$ of congregations in rural areas. Most of the clergy $(89.4 \%)$ did not have a specific portfolio in their congregation, but were involved in general ministry, while only $4.9 \%$ worked exclusively with youth, and $2.1 \%$ mainly worked as counsellors.

The only significant difference in demographic attributes of clergy was that female clergy were significantly younger (median age $=38$ years) than their male colleagues (median age $=56$ years), $U=228.5, z=-4.047, p=0.000, r=0.34$.

\section{Perceptions of young people and their sexual behaviour}

Most (76.8\%) of the clergy agreed that the young, unmarried people in their congregations are sexually active and $87.3 \%$ further agreed that the general South African statistics, suggesting that youth are sexually active from an early age, are also applicable to the young people in the Afrikaansspeaking churches.
There was great empathy with the challenges facing young people today. Most clergy agreed that young people today find it difficult to adhere to the norms of sexual abstinence before marriage and faithfulness to one partner, and they contributed this to the following factors:

- disillusionment with their parents' marriages that often include unfaithfulness and divorce (88.7\%)

- questioning and undermining the authority of parents, the church, people in power positions and questioning of traditions $(86.6 \%)$

- a society that 'supports' multiple sex partners (e.g. through television and the film industry) (92.3\%)

- young people's search for an own identity often leading to unhealthy sexual relationships (95.1\%)

- young people's search for intimacy and acceptance by peers and others $(90.1 \%)$.

\section{Is it the task of the church to provide sexuality education to young people?}

Most clergy (86.6\%) believed that it is the responsibility and task of the church to protect young people from HIV by providing sexuality education to young people and to specifically inform them about high-risk sexual behaviour and the prevention thereof. Most of the clergy (75.4\%) also believed that the church should become involved in local schools where they could play an active role in providing sexuality education (including HIV prevention), while 22.5\% of the participants felt that the church should provide guidance for parents of adolescents on how to talk to their children about sex, rather than doing it themselves. Only 13.4\% clergy believed very strongly that it is not the task of the church to give sex education to young people in their congregations.

\section{Clergy's involvement in HIV education for young people}

Not many clergy, who participated in the study, were involved in sexuality education for young people. Only $4.9 \%$ of clergy worked with young people (or had 'Youth' as their portfolio), while $47.9 \%$ did not feel equipped or empowered to give information about HIV to young people. HIV prevention programmes for young people were provided by only $19.7 \%$ of clergy, with only $13.4 \%$ of these programmes being offered in the clergy's own congregations. HIV awareness days (like World AIDS Day on 01 December) were offered by only $17.6 \%$ clergy, with only $14.8 \%$ of these programmes or activities were offered in clergy's own congregations. Some clergy (16.2\%) gave attention to gender issues in their congregations by talking to boys and young men about having respect for the female body. Two-thirds (65.5\%) of clergy said that they received no (or very little) support from church leaders and synod on how to manage HIV in their parishes.

\section{HIV prevention message to young people}

Clergy were asked to choose the one most appropriate and theologically sound message about the prevention of HIV that they were prepared to share with young, unmarried 
parishioners (see Table 1). (Prevention messages to adult parishioners were discussed in Van Dyk [2017b].)

The kind of messages about HIV prevention that clergy were prepared to share with their young parishioners can be divided into three groups (see Figure 1).

The three groups of HIV prevention messages that clergy were prepared to share with young people were:

- Strict church doctrine ('Your body is the temple of God and therefore you have to live a healthy life on all levels, also the sexual level'). The majority of clergy (64.1\%) chose to give this message to young, unmarried people in their congregations to prevent HIV infection.

- Abstinence only ('Total abstinence until marriage'). The 'abstinence only' message was the main HIV prevention message of $20.4 \%$ of clergy.

- Abstinence plus safer sex. If young people chose not to abstain from sex until they are married, $15.5 \%$ of clergy were prepared to give the following safer sex messages: Use condoms if you have sex (4.2\%); faithfulness to one partner at a time with condom use (4.2\%); postpone initiation of sexual intercourse for as long as possible $(3.5 \%)$ and restrict the number of sexual partners to the minimum $(0.7 \%)$. Some clergy $(2.8 \%)$ suggested a combination of the safer sex practices mentioned above.

TABLE 1: HIV prevention message to young parishioners ( $n=142$ ).

\begin{tabular}{lcc}
\hline HIV prevention message to young parishioners & $\mathbf{\%}$ & $\boldsymbol{n}$ \\
\hline $\begin{array}{l}\text { Your body is the temple of God and therefore you have to } \\
\text { live a healthy life on all levels, also on the sexual level }\end{array}$ & 64.1 & 91 \\
Total abstinence until marriage & 20.4 & 29 \\
Faithfulness to one sex partner at a time with condom use & 4.2 & 6 \\
Use condoms if you cannot abstain from sex & 4.2 & 6 \\
Postpone sexual intercourse for as long as possible & 3.5 & 5 \\
Restrict your number of sex partners & 0.7 & 1 \\
Combination of abstinence, faithfulness and condom use & 2.8 & 4 \\
\hline
\end{tabular}

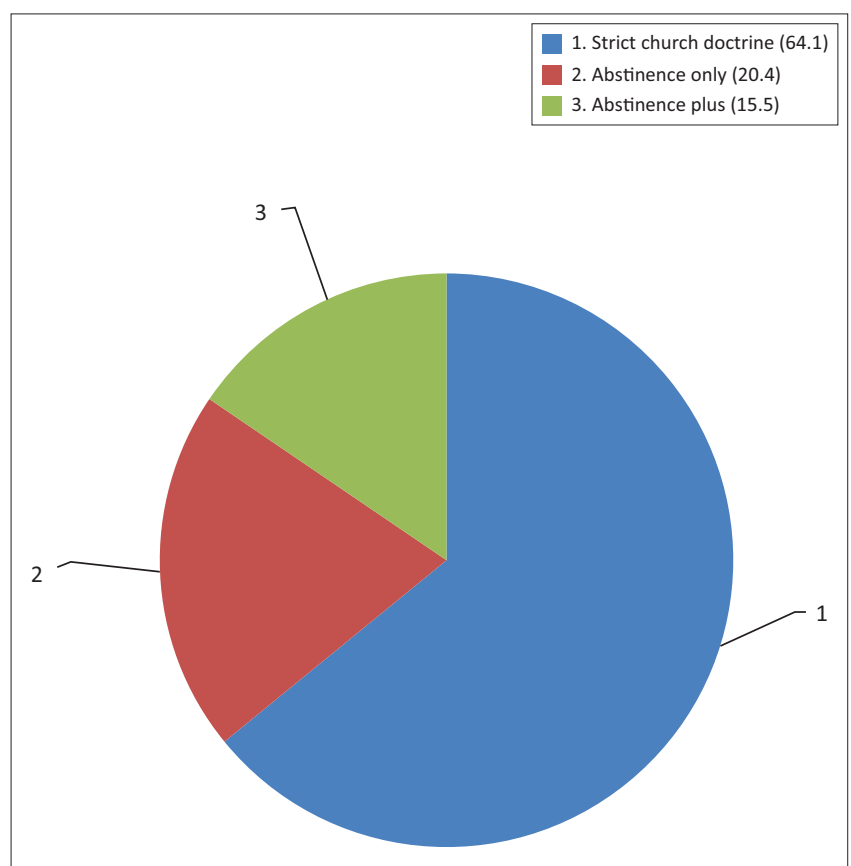

FIGURE 1: Clergy's HIV prevention message to youth ( $n=142)$.
Negative attitudes towards the use of condoms were illustrated by the finding that only $4.2 \%$ clergy were prepared to tell young people to use condoms (see Table 1). A further $40.8 \%$ believed that to talk about condoms will undermine the main message of the church (abstinence and faithfulness) and will encourage sexual promiscuity. Some clergy (34.5\%) believed that to talk to young, unmarried people about condoms 'has absolutely no place in the church'.

Achi-square test revealed that female clergy were significantly more prepared to give 'abstinence plus safer sex' messages to young people than their male colleagues $(X=12.04, d f=2$, $n=142, p=0.002)$. While $50 \%$ of female clergy chose 'abstinence plus safer sex' practices as their main HIV prevention message, only $12.3 \%$ male clergy chose this option as their main HIV prevention message. Male clergy were more inclined to repeat church doctrine ('the body as temple of God') as HIV prevention message (66.2\%) than female clergy (41.7\%). Although the difference between male and female clergy's HIV prevention messages was statistically significant, the finding should be read with caution because the sample of women who participated in the study was small $(n=12)$ and no supporting literature could be found.

\section{Discussion}

\section{Clergy's perceptions of young congregants and their sexual behaviour}

Clergy from the white Afrikaans-speaking churches in the Reformed traditions, who participated in the study, showed great empathy for the challenges that young people must face in today's society. They agreed with researchers (like Bornman 2013:2-4; Steyn \& Lotter 2006:550-552; Van Dyk 2017a:283-290) that developmental and social factors make it very difficult for young people to adhere to the moral norms of sexual abstinence until marriage and absolute faithfulness thereafter. These factors include the adolescent's search for identity, intimacy and acceptance, peer pressure, the influence of social and other media, and disillusionment because of parental unfaithfulness and divorce. Clergy were also very realistic about the sexual behaviour of young unmarried people in their congregations, and they realised that young Afrikaans-speaking churchgoers are not exempted from HIV infection. This concern for young congregants was also evident in the research of Mash et al. (2006), Nweneka (2007) and Mash and Mash (2013).

\section{Is it the task of the church to provide sexuality education to young congregants?}

Most clergy in the current study agreed that it is the task of the church to provide sexuality education and HIV prevention to young people in their congregations. A minority clergy thought that the church should only provide guidance to parents on how to talk to young people about sex and HIV prevention. This finding is in contrast to the findings of Eriksson et al. (2010:109), who found that most clergy did not see it as the responsibility of the church to provide HIV prevention information, but viewed it as the task of parents to educate their children about sexuality and HIV prevention. 
Clergy also felt very strongly that the church should become more involved with local schools to play an active role in sexuality education of the youth. Throughout history, the church played a major role in the development of society in southern Africa, including its schools, education and healthcare systems, and many schools had their origins through the church. However, in a report on the role of the NG Church in education, a committee of the general synod concluded that the church has lost her voice in schools in the new political dispensation and that the church neglected her responsibilities towards schools and young people (Moderamen Bylaag 2: Die rol van die NG kerk in die onderwys 2013:220-221). The committee made several suggestions on how the church should become actively involved in schools again. One of these suggestions was 'die vestiging van ' $n$ waardegedrewe en etiese gemeenskap' [the establishment of a value-driven and ethical community] with reference to violence, teenage pregnancy, lack of discipline and other forms of misbehaviour. This same report did not once mention the words 'sexuality', 'HIV or AIDS' or 'prevention of HIV'. However, the report clearly stated the NG Church's position on marriage ('sex outside marriage is not according to church regulations').

Apart from its role in schools, the church can play an extremely important role in reaching out-of-school youth - a category that evades school-based interventions. Focus on the out-of-school youth is especially important because research among South African youths found that they were significantly more associated with early sexual debut, age-disparate partners, multiple sex partners, transactional sex, high lifetime number of partners, low HIV risk perceptions, inconsistent condom use and low health literacy (Stroeken et al. 2011:186).

\section{Clergy's involvement in HIV education for young people}

Although the majority of clergy $(86.6 \%)$ agreed that it is the task of the church to offer sexuality education (including the prevention of HIV) to young people in their congregations, not many clergy (only 13.4\%) were involved in sexuality education of young people in their own congregations. These findings correspond with the findings of Eriksson et al. (2010:107) who, in their interviews with clergy in South Africa, also found silence, ambivalence and fear of conflict with the church hierarchy should they talk to young people about sex and HIV prevention. As was found in the current study, the clergy in Eriksson et al.'s (2010:108) study also complained that they did not get a lot of support from church leaders, and that they felt isolated when dealing with the increasing demands of the epidemic (also see Van Dyk 2017b). The easiest way out is then often to do nothing or to do just the bare minimum.

One would expect that clergy will make use of the opportunity provided by special HIV awareness days like World AIDS Day to talk to young people about sexuality and HIV prevention, but very few clergy $(14.8 \%)$ in the current study used that opportunity. This corresponds to the lack of interest in HIV among the clergy in Eriksson et al.'s (2010:108) study, who limited their interventions by 'talking about HIV in youth meetings once or twice a year'.

\section{The main HIV prevention message to young congregants}

Clergy in this study were very realistic about the sexual activities of young unmarried people in their congregations and their risk of HIV infection and other STIs. They further strongly believed in the task of the church to provide sexuality education and HIV prevention messages. With the scientific or medical model in mind, one would expect that these positive attitudes of clergy will translate into comprehensive education programmes that have proven success in delaying sexual debut, limiting sex partners and reducing the rates of HIV infection. This is, however, clearly not the case. The religion or moral versus science dichotomy that Genuis (2010:187) referred to is clearly also present in the prevention messages that clergy in the current study are prepared to share with young people, as is evident from the messages they were willing to share with the youth.

\section{Abstinence only}

The findings of this study - that almost $85 \%$ of clergy supported 'abstinence only', or 'body as temple of God' as HIV prevention messages - correspond with many other studies who also found that the main HIV prevention message of ministers to young people is to abstain from sex until marriage (e.g. Blevins 2016:37; Eriksson et al. 2013, 2014:1668; Francis 2009:6; Santelli et al. 2006:85). However, behaviour change theorists would see the message 'the body as the temple of God' as rather vague and even ambiguous because it does not spell out exactly what a 'healthy lifestyle' entails or precisely how such a lifestyle protects one against HIV and other STIs (Ajzen 2005; Fishbein \& Middlestadt 1989; Van Dyk et al. 2017:186-208).

Most researchers further agree that 'abstinence only' messages do not protect young people from HIV and is basically irrelevant in a population where young people are already sexually active. Abstinence only messages may also stigmatise premarital sexual relationships and drive young people 'underground', which means that they will not have the courage to ask for help on how to, for example, negotiate condom use with partners (Smith 2004:434).

Sex in young people is often a complex matter involving power issues, non-sexual needs, loneliness, mental health issues, abuse, survival, social pressures and social expectations (Cohen 1995:24-29). A one-dimensional, simplistic intervention strategy of sexuality education like 'abstinence only' will therefore not only be ineffective but may also put young people in harm's way by not addressing the issues mentioned above. It will also not prepare young people for sex, which in today's society will most probably be initiated before marriage. The danger of 'abstinence only' messages is that it may silence young people from any 
deeper discussions on sexuality and safer sex (Francis \& DePalma 2014:84).

\section{Comprehensive HIV prevention programmes}

Only $15.5 \%$ of clergy in the current study were prepared to share a more comprehensive HIV education message for young people in their congregations. Comprehensive sexuality education (CSE) (often called 'abstinence plus' education) entails a message of abstinence PLUS postponement of sexual intercourse for as long as possible PLUS faithfulness to one partner PLUS condom use PLUS restriction of the number of sex partners to the minimum.

Although 'abstinence only' and CSE seem to be two contradictory positions, they can be strategically combined to allow young people to make responsible choices without alienating them through moralism only (Francis \& DePalma 2014:81; Lesko 2010:281-97). CSE, which emphasises the benefits of abstinence while also teaching young people about contraception and disease-prevention methods, has been proven to reduce rates of teen pregnancy, STIs and HIV infection (Genuis 2010:187; Kirby 2008:26). CSE often changes young people's attitudes to sexuality completely, significantly increasing the number of adolescents who delay sexual debut and limit their number of partners. These informed adolescents also know how to protect themselves and their partners from HIV and STIs once they become sexually active.

\section{Attitudes towards condoms}

Negative attitudes of clergy towards condoms were suggested by the finding that very few clergy were prepared to tell young people to use condoms because they belief that talking about condoms has no place in the church and that it will encourage young people to have sex and will lead to promiscuity (also see Eriksson and colleagues' findings 2010:111). One of the reasons for this negativity is probably because most of the earlier HIV prevention programmes were too narrowly condom-focused instead of offering a more comprehensive approach such as the CSE programmes.

The belief that talking about condoms encourages young people to have sex is also unfounded. Extensive research was performed on this topic and researchers came to the conclusion that there was no increase in sexual activity after adolescents were exposed to sexuality and HIV education programmes, including information on contraceptives and condom use (Kirby 2008:18; Kirby, Laris \& Rolleri 2007). Good-quality sexuality and HIV education programmes do not increase sexual behaviour, but rather prepare young people for a responsible lifestyle. HIV prevention programmes should never consist of condom use messages only. Genuis (2010:185), for example, found that although condom usage is an effective strategy for reducing HIV transmission, these initiatives did not achieve their desired epidemiological impact in the real world. The importance of providing CSE cannot be stressed enough.

\section{Conclusion What should the church do?}

Blevins (2016:37) believes that the ongoing global response to HIV should include specific initiatives to equip clergy, the church and FBOs to provide comprehensive HIV prevention and sexual health services so that our youth might have the opportunity to live responsible, full, healthy and HIV-free lives. It is clear from the current findings that most clergy realised that many young people do have sex before marriage, and that it is the task of the church to get involved in HIV prevention initiatives. But when it comes to the practical side of HIV prevention, very few clergy were involved in HIV prevention programmes, and the HIV prevention message that they were prepared to share with young people was not a clear, helpful message at all. It is important for church leaders and the relevant synods to take a stand and empower clergy to get involved in the sexual health of their young parishioners by offering realistic guidance to them, rather than clinging to ideological stances, which have been proven to be ineffective.

Comprehensive HIV prevention programmes should, however, offer more than mere guidance about sexuality. It should include religious activities, which teach life skills and increase spiritual well-being, self-efficacy, self-esteem and pro-social behaviour in young people (Jacobs et al. 2012; Wild et al. 2004). Issues such as peer pressure, gender power relations and building trust in close relationships between young men and women should also be addressed. Young women should be empowered with skills which would enable them to resist pressure to engage in unwanted sex and to practise safer sex (Marshall \& Taylor 2006:363-347).

The power of spiritual well-being and its effect on healthy lifestyle choices in adolescents should not be underestimated. Jacobs et al. (2012:96) found a significant correlation between the spiritual well-being of Afrikaans-speaking adolescents and the lifestyle choices they made. Adolescents who made sex part of their lifestyles, who tried to commit suicide before, who smoked and drank alcohol had significantly lower scores on spiritual well-being than adolescents who chose a healthy lifestyle. It is therefore important for clergy to include spiritual well-being into comprehensive HIV prevention programmes.

HIV prevention messages should be in line with the lived experiences and reality of its youth. Eriksson et al. (2014:1670) asked young people between 15 and 24 years of age what they want from their local churches. They responded that church leaders should tell them how to abstain from premarital sex instead of only preaching the moral rule of abstinence. They further specifically asked for guidance on safer sex, HIV and STI prevention, prevention of pregnancy and education on relationships. Is it not time that we ask young people in our congregations what they expect from us?

Francis and DePalma (2014:84) made the comment that we tend to see young people as 'children in need of our 
protection'. We need, however, to reflect on our own attitudes towards young people and rather see them as 'positive, active sexual beings who have the right to relevant information about their own bodies and sexuality'. We can no longer afford to alienate young people through moralism only. We need an approach that satisfies both morality and reality.

\section{Shortcomings of this study}

The current study should be seen as an initial exploration on how clergy in the white Afrikaans-speaking churches in the Reformed tradition are dealing with sexuality and HIV prevention with regard to young people in their congregations. The results of the study cannot be generalised to all the clergy in the white Afrikaans-speaking churches because the sample was a convenient sample only and not a randomised sample. The sample size (142 clergy) was also relatively small. More comprehensive studies need to be conducted among clergy as well as young congregants to learn more about what they expect from the church and her leaders.

\section{Acknowledgements Competing interests}

The author declares that she has no financial or personal relationships that may have inappropriately influenced her in writing this article.

\section{References}

Ajzen, I., 2005, Attitudes, personality and behaviour, Open University Press, Berkshire. Blevins, J., 2016, 'Are faith-based organizations assets or hindrances for adolescents living with HIV? They are both', The Brown Journal of World Affairs XXII(II), 25-38.

Bornman, M.J., 2013, 'Die invloedsverlies van die kerk as geloofsgemeenskap op Christen adolessente se besluite rondom seksualiteit', In die Skriflig/In Luce Verb 47(1), Art. \#95, 9p. https://doi.org/10.4102/ids.v47i1.95

Burchardt, M., 2011, 'Challenging Pentecostal moralism: erotic geographies, religion and sexual practices among township youth in Cape Town', Culture, Health \& Sexuality 13(6), 669-683. https://doi.org/10.1080/13691058.2011.566356

Cohen, M., 1995, 'Adolescent sexual activity as an expression of nonsexual needs', Pediatric Annals 24, 324-329. https://doi.org/10.3928/0090-4481-19950601-10

Coolican, H., 2004, Research methods and statistics in psychology, 4th edn., Hodder \& Arnold, London.

Denis, P., 2009, 'The church's impact on HIV prevention and mitigation in South Africa. Reflections of a historian', Journal of Theology for Southern Africa 134, 66-81.

Erasmus, J. \& Le Roux, M., 2008, Baseline study about sexuality and AIDS among 10 to 24 year old members in the 19 selected dioceses, University of Stellenbosch: Unit for Religion and Development Research, Stellenbosch.

Eriksson, E., Lindmark, G., Axemo, P., Haddad, B. \& Ahlberg, B.M., 2010, 'Ambivalence, silence and gender differences in church leaders' HIV-prevention messages to young people in KwaZulu-Natal, South Africa: Short Report', Culture, Health \& Sexuality 12(1), 103-114. https://doi.org/10.1080/13691050903141192

Eriksson, E., Lindmark, G., Axemo, P., Haddad, B. \& Ahlberg, B.M., 2013, 'Faith, premarital sex and relationships: Are church messages in accordance with the perceived realities of the youth? A qualitative study in KwaZulu-Natal, South Africa', Journal of Religion and Health 52(2), 454-466. https://doi.org/10.1007/ s10943-011-9491-7

Eriksson, E., Lindmark, G., Haddad, B. \& Axemo, P., 2014, 'Young people, sexuality, and HIV prevention within Christian faith communities in South Africa: A crosssectional survey', Journal of Religion and Health 53(6), 1662-1675. https://doi. org/10.1007/s10943-013-9753-7

Fishbein, M. \& Middlestadt, S.E., 1989, 'Using the theory of reasoned action as a framework for understanding and changing AIDS-related behaviours', in V.M.
Mays, G.M. Albee \& S.F. Schneider (eds.), Primary prevention of AIDS: Psychological Mays, G.M. Albee \& S.F. Schneider (eds.), Primary prevention
approaches, pp. 93-110, Addison-Wesley, Reading, MA.

Francis, D.A. \& DePalma, R., 2014, 'Teacher perspectives on abstinence and safe sex education in South Africa', Sex Education 14(1), 81-94. https://doi.org/10.1080/ 14681811.2013.833091

Francis, S.A., 2009, 'A review of faith-based HIV prevention programs', Journal of Religion and Health 48, 6-15. https://doi.org/10.1007/s10943-008-9171-4

Garner, R.C., 2000, 'Safe sects? Dynamic religion and AIDS in South Africa', Journal of ModernAfrican Studies 38(1), 41-69. https://doi.org/10.1017/S0022278X99003249
Genuis, S.J., 2010, 'Adolescent sexual behaviour and public health: The religion versus science dichotomy', Acta Paediatrica 99(2), 185-187. https://doi.org/10.1111/ science dichotomy', Acta
j.1651-2227.2009.01557.x

Gold, M.A., Sheftel, A.V., Chiappetta, L., Young, A.J., Zuckoff, A., DiClemente, C.C. et al., 2010, 'Associations between religiosity and sexual and contraceptive behaviors', Journal of Pediatric and Adolescent Gynecology 23(5), 290-297. https://doi. org/10.1016/j.jpag.2010.02.012

Jacobs, A.C., Viljoen, C.T. \& van der Walt, J.L., 2012, 'Spiritual well-being and lifestyle choices in adolescents: A quantitative study among Afrikaans-speaking learners in the North West Province of South Africa', Journal of Child \& Adolescent Mental Health 24(1), 89-98. https://doi.org/10.2989/17280583.2012.673493

Jansen, C.A., Pretorius, F.J. \& van Niekerk, E.J., 2009, 'Education and the role of the church in Africa: Three relevant aspects', Koers 74(1\&2), 67-85. https://doi.org/ 10.4102/koers.v74i1/2.117

Kirby, D., 2008, 'The impact of abstinence and comprehensive sex and STD/HIV education programs on adolescent sexual behavior', Sexuality Research and Socia Policy 5(3), 18-27. https://doi.org/10.1525/srsp.2008.5.3.18

Kirby, D.B., Laris, B.A. \& Rolleri, L.A., 2007, 'Sex and HIV education programs: Their impact on sexual behaviors of young people throughout the world', Journal of AdolescentHealth40(3),206-217.https://doi.org/10.1016/j.jadohealth.2006.11.143

Lesko, N., 2010, 'Feeling abstinent? Feeling comprehensive? Touching the affects of sexuality curricula', Sex Education 10(3), 281-297. https://doi.org/10.1080/14681 811.2010.491633

Marshall, M. \& Taylor, N., 2006, 'Tackling HIV and AIDS with faith-based communities: Learning from attitudes on gender relations and sexual rights within local evangelical churches in Burkina Faso, Zimbabwe and South Africa', Gender and Development 14(3), 363-374. https://doi.org/10.1080/1355207 Gender and
0600980344

Mash, R. \& Mash, R., 2013, 'Faith-based organisations and HIV prevention in Africa: A review', African Journal of Primary Health Care \& Family Medicine 5(1) viewed 16 February 2017, from http://www.phcfm.org./index.php/phcfm/ viewed 16 Februar

Mash, R., Kareithi, R. \& Mash, B., 2006, 'Survey of sexual behaviour among Anglican youth in the Western Cape', South African Medical Journal 96(2), 124-127.

Moderamen Bylaag 2: Die rol van die NG kerk in die onderwys, 2013, viewed 12 January 2016, from http://www.ngkerkas.co.za/index.php/taakspanne-virstaande-werk/projekte/onderwys/

Mpofu, E., Nkomazana, F., Muchado, J.A., Togarasei, L. \& Bingenheimer, J.B., 2014, 'Faith and HIV prevention: The conceptual framing of HIV prevention among Pentecostal Batswana teenagers', BMC Public Health 14(1), viewed 29 January 2017, from http://bmcpublichealth.biomedcentral.com/articles/10.1186/1471-2458-14-225

Müller, J.C. \& Pienaar, H.E., 2003, 'A socio-constructionist, narrative understanding of the Church's morality on sex', Verbum et Ecclesia 24(1), 137-155.

Nweneka, C.V., 2007, 'Sexual practices of church youth in the era of HIV/AIDS: Playing theostrich', AIDSCare19(8),966-969.https://doi.org/10.1080/09540120701249512

Rostosky, S.S., 2004, 'The impact of religiosity on adolescent sexual behavior: A review of the evidence', Journal of Adolescent Research 19(6), 677-697. https://doi. org/10.1177/0743558403260019

Santelli, J., Ott, M.A., Lyon, M., Rogers, J. \& Summers, D., 2006, 'Abstinence-only education policies and programs: A position paper of the Society for Adolescent Medicine', Journal of Adolescent Health 38(1), 83-87. https://doi.org/10.1016/j. jadohealth.2005.06.002

Shisana, O., Rehle, T., Simbayi, L.C., Zuma, K., Jooste, S., Zungu, N. et al., 2014, South African national HIV prevalence, incidence and behaviour survey, HSRC Press, Cape Town.

Smith, D.J., 2004, 'Youth, sin and sex in Nigeria: Christianity and HIV/AIDS-related beliefs and behaviour among rural-urban migrants', Culture, Health \& Sexuality 6(5), 425-437. https://doi.org/10.1080/13691050410001680528

Stephenson, R., Simon, C. \& Finneran, C., 2014, 'Community factors shaping early age at first sex among adolescents in Burkina Faso, Ghana, Malawi and Uganda', Journal of Health, Population \& Nutrition 32(2), 161-175.

Steyn, R.S. \& Lotter, G.A., 2006, 'Veranderende tendense en die implikasies vir jongmensverhoudings', Koers 71(2,3,4), 535-555.

Stroeken, K., Remes, P., De Koker, P., Michielsen, K., Van Vossole, A. \& Temmerman M., 2011, 'HIV among out-of-school youth in Eastern and Southern Africa: A review', AIDS Care July, 1-9. https://doi.org/10.1080/09540121.2011.596519

Van Dyk, A., 2017a, 'AIDS education for school children', in A. Van Dyk, E. Tlou \& P. Van Dyk, HIV and AIDS education, care and counselling. A multicultural approach, 6th edn., pp. 251-308, Pearson Education, Cape Town.

Van Dyk, A., Tlou, E. \& Van Dyk, P., 2017, HIV and AIDS education, care, counselling. A multicultural approach, 6th edn., Pearson Education, Cape Town.

Van Dyk, A.C., 2017b, "“Go in peace - And die!" The task of the church in the AIDS context', Verbum et Ecclesia 38(1), 9p. https://doi.org/10.4102/ve.v38i1.1752

Wild, L.G., Flisher, A.J., Bhana, A. \& Lombard, C., 2004, 'Associations among adolescent risk behaviours and self-esteem in six domains: Self-esteem and adolescent risk behaviours', Journal of Child Psychology and Psychiatry 45(8), 1454-1467. https:// doi.org/10.1111/j.1469-7610.2004.00330.x

Yaw Amoateng, A. \& Kalule-Sabiti, I., 2013, 'Social structure and sexual behaviour of Black African adolescents in the North West Province, South Africa', South African Review of Sociology 44(1), 131-157. https://doi.org/10.1080/2152 8586.2013.784453

Zaleski, E.H. \& Schiaffino, K.M., 2000, 'Religiosity and sexual risk-taking behavior during the transition to college', Journal of Adolescence 23(2), 223-227. https:// doi.org/10.1006/jado.2000.0309 